\section{Katarzyna Trzeciak}

Uniwersytet Jagielloński

\section{Przeciwko zasadzie podobieństwa}

\author{
O książce Joanny Bednarek Życie, które \\ mówi. Nowoczesna wspólnota i zwierzęta
}

\begin{abstract}
Against the Sameness Principle

The article is a review of Joanna Bednarek's book Życie, które mówi. Nowoczesna wspólnota i zwierzęta [A Life that Speaks. The Modern Community and Animals]. In her book, Bednarek aims at redefining the question of animals (especially non-human beings) and their presence in the community of all animate beings. She goes against the utilitarian and abolitionist movements claiming that animals should have equal rights to human beings because of their similarity, either in their sensibility or in their non-questionable biological lives. Bednarek proposes a critical return to Spinosian ontology (through the lens of Deleuzian interpretation and biosemiotics), and argues for a community of beings based on their ability to speak (precisely, their ability to create signs). Linking some points from agential realism and new materialism with the Rancièrian concept of a community, Bednarek shows how we can go beyond the sameness principle and build our solidarity with non-human beings on their relation, not only with us, but with all the nonliving environment.
\end{abstract}

Słowa kluczowe: animal studies, zwierzę, mowa, wspólnota, posthumanizm

Keywords: animal studies, animal, speech, community, posthumanism 
6 czerwca 1881 roku w nowojorskiej bazie szkoły wojskowej przeprowadzono osobliwy eksperyment, szczególną lekcję dla młodych żołnierzy, połączoną z prezentacją najnowszych zdobyczy fotografii. Innowację w postaci światłoczułych żelatynowych płytek ukazano na przykładzie sceny ze zwierzęciem, mułem, któremu do głowy przymocowano wypełniony dynamitem woreczek, połączony $\mathrm{z}$ aparatem fotograficznym. Otwarcie migawki, inicjujące zdjęcie, spowodowało wybuch. Stare już zwierzę zostało poświęcone na ołtarzu nauki, a rezultatem tego poświęcenia stało się zdjęcie, przedstawiające bezgłowego muła na chwilę przed upadkiem. „Fotografia ta uchwytuje doskonale figurę zwierzęcia, które staje się nieme i nieludzkie na mocy pojedynczego gestu spojrzenia, ustanawiającego relację pomiędzy nim a światem społecznym"'. Acefaliczny, niemy muł staje się bezrozumną bestią, nie-ludzkim bytem, powstałym jednakże wskutek działania na wskroś ludzkiego - naukowego i postępowego spojrzenia. Ucieleśnione w migawce aparatu spojrzenie wytycza granicę - to, co ludzkie, powołuje w obrazie dziki, w niczym niepodobny do człowieka byt, w dodatku swoją dzikością i nieprzewidywalnością zagrażający jasnej domenie ludzkiego rozumu.

Dziewiętnastowieczne uzasadnienie, formuła mówiąca o poświęceniu zwierzęcia na ołtarzu nauki i cywilizacyjnego rozwoju, pobrzmiewa $\mathrm{w}$ artykule 3 Kodeksu norymberskiego, który wymaga, by każdy eksperyment medyczny oparty był na rezultatach doświadczeń przeprowadzonych na zwierzętach. Jednocześnie $\mathrm{w}$ tym samym artykule sformułowana jest zasada koniecznej minimalizacji cierpień fizycznych i psychicznych „osób podległych eksperymentowi”. W formule tej dobitnie wybrzmiewa przekonanie o kategorialnej wyższości osób nad innymi podmiotami życia, pozbawionymi atrybutów osoby².

Jednym ze sposobów przezwyciężania zarysowanych tu podziałów jest współcześnie stanowisko utylitarystów (Petera Singera, promującego wraz z Paolą Cavalieri organizację The Great Ape Project), przyznających prawa szympansom na podstawie zasady podobieństwa do człowieka - zwierzęta (niektóre) są zdolne do cierpienia, odczuwania przyjemności, a także dysponują modelami kognitywnymi, które pozwalają im np. na naukę języka, analogicznie do ludzi. Druga ze ścieżek, zmierzająca jednak tą samą drogą analo-

1 M. Janik, Polityka nie-polityczności - nieme zwierzęta i posthumanizm, „Praktyka Teoretyczna" 2014, nr 4, s. 190.

2 Według obecnego stanu badań - pisał zoologii i bioetyk Andrzej Elżanowski niektóre ptaki i ssaki spełniają podstawowe warunki bycia osobami, cechuje je bowiem świadomość refleksyjna i racjonalność. Jakkolwiek, wskazywał badacz, „obecny dyskurs bioetyczny jest fatalnie obciążony przez aprioryczne i anachroniczne dychotomie ludziezwierzęta i osoby-rzeczy", które ignorują silne zróżnicowanie wewnątrz poszczególnych członów tych opozycji (A. Elżanowski, O podmiotach osobowych i nieosobowych, „Znak” 2015, nr 5 (720), s. 18). 
gii, prowadzi do dyskursu praw zwierząt, czyli przyznania niektórym (znów!) zwierzętom praw analogicznych do ludzkich na podstawie niepodlegających negocjacjom (jak w przypadku utylitarystów) wrodzonych wartości życia ${ }^{3}$.

W obu stanowiskach, posługujących się odmiennymi argumentami, wybrzmiewa postulat antropocentrycznego włączania i nadawania praw przez hierarchiczną zasadę podobieństwa, utwierdzającą ludzką protekcję i kuratelę. A zatem podtrzymują one trzon struktury nowożytnej polityki, która dzieli istoty żywe „na bardziej i mniej wartościowe, lepiej i gorzej spełniające kryteria człowieczeństwa"4.

$\mathrm{Z}$ problematyczności tych postulatów, jak też $\mathrm{z}$ ich genezy zdaje sprawę książka Joanny Bednarek, Życie, które mówi. Nowoczesna wspólnota $i$ zwierzęta. W eseju tym skupiają się wszystkie wymienione przeze mnie figury oraz wątki: geneza zwierzęcia jako niemego, bestialskiego bytu i próby włączania zwierząt do ludzkiej wspólnoty. Ale nie jest to książka, której przedmiotem byłaby wyłącznie precyzyjna rekonstrukcja nowoczesnego wykluczenia i współczesnych negocjacji granic wspólnoty. Joanna Bednarek dąży do ukazania, że „nie-ludzkie zwierzęta nie tyle powinny należeć do wspólnoty, co już do niej należą (i pozostaje tylko wyciągnąć z tego odpowiednie konsekwencje)"s. Jest to więc próba przekroczenia dyskursu praw zwierząt, opartego na zasadzie podobieństwa, na rzecz wspótistnienia, którego zwornikiem jest mowa - wytwarzanie znaków. Tak określony cel projektu sprowadza się zatem nie tylko do ,przemyślenia na nowo statusu zwierząt”, ale oznacza przede wszystkim ,przemyślenie kształtu i natury samej wspólnoty (w tym tego, co właściwie oznacza »mówienie«)" (s. 22).

Obszerny esej podzielono na części, w których autorka, niebezpośrednio, rozwija znaczenia słów składających się na tytuł książki. Zaczyna od prezentacji najszerszej ramy nowoczesnej wspólnoty politycznej, a następnie poddaje analizie interesujące ją akty założycielskie refleksji o zwierzętach (Karte-

3 Interesujący przykład negocjacyjnego podejścia do kwestii życia prezentuje Tom Regan, który uważa, że wartość życia wzrasta wraz z poszerzaniem puli satysfakcji z zaspokojonych preferencji. Twierdzi on, że jakkolwiek „,dzielimy z innymi zwierzętami wiele odczuć, ludzka pula jest większa, a więc szkoda w przypadku ich [ludzi - przyp. K.T.] śmierci jest bardziej dotkliwa. W tym sensie uznaje więc wyjątkowość człowieka i jego odmienność od innych zwierząt” (D. Gzyra, Problem zwierząt. Jak postrzegamy i jak traktujemy zwierzęta?, „Jednak Książki. Gdańskie Czasopismo Humanistyczne” 2014, nr 2, s. 16). Autor omówienia teorii Regana zwraca jednak uwagę, że prawa zwierząt istnieją obok praw człowieka, człowiek jest bowiem wyłączony z obszaru praw zwierząt.

4 J. Bednarek, Emancypacyjna obietnica posthumanizmu, „Praktyka Teoretyczna”, http://www.praktykateoretyczna.pl/joanna-bednarek-emancypacyjna-obietnica-posthumanizmu/\#_ftn6 [dostęp: 5.05.2018].

5 Eadem, Życie, które mówi. Nowoczesna wspólnota i zwierzęta, Warszawa 2017, s. 21. Dalsze cytaty z tej książki lokalizuję bezpośrednio w tekście, podając w nawiasie numer strony. 
zjusza i Spinozy), rolę figur jedności i wielości w prozwierzęcej teorii (rewizja Lévinasowskiej etyki i interpretacja „stawania się”), krytykę „negatywnego” nurtu biopolityki, a wszystko po to, by w ostatniej, tytułowej części zaproponować ciekawe teoretycznie i afirmatywne wobec życia podejście do etyki w poszerzonym polu, uwolnionym od kategorii osoby, a przy tym nieredukowalnie związanym ze wspólnotą polityczną za pomocą mowy. Wszystkimi częściami rządzi zasada podejrzliwości, która ujawnia się na końcu każdej $\mathrm{z}$ nich i zarazem uzasadnia rekonstrukcję przywoływanych koncepcji.

W swoim omówieniu nie będę rekonstruować treści i konkluzji poszczególnych rozdziałów Życia, które mówi..., postaram się jedynie wydobyć oryginalność niektórych postulatów autorki, oświetlając je niekiedy innymi współcześnie rozwijanymi propozycjami nieantropocentrycznej ontologii.

Joanna Bednarek, wskazując na podstawowe mechanizmy nowoczesnego opisywania świata (by na ich podstawie określić możliwości emancypacyjne w nowoczesnej wspólnocie politycznej), podąża za Brunonem Latourem, ujawniającym fundamentalny dla nowoczesności podział na świat rzeczy, którym zajmuje się nauka, i świat ludzi, będący domeną polityki. W tym podziale natura jest zewnętrzna wobec polityczności, a jednocześnie ją uprawomocnia. Paradoks stanu natury polega na jednoczesnej nieciągłości i kontynuacji, naturalne uprawnienia są bowiem podstawą dla praw ludzkich w stanie uspołecznienia, a jednocześnie sam człowiek okazuje się jedyną istotą mogącą złamać prawa natury. $\mathrm{W}$ stanie uspołecznienia natura istnieje $\mathrm{w}$ postaci opozycji sfery polityczności i prywatności. Prywatność to domena naturalności człowieka, uznanej za apolityczną, czy nawet bliską tej, którą dzielimy ze zwierzętami. Sfera prywatna, domowa jest też skutecznym narzędziem pacyfikacji cech podmiotów politycznych - ci, którym odmawia się tych cech, są relegowani do przestrzeni oddzielonej od życia publicznego, z której nigdy nie może się dobywać głos wspólnotowy, zbiorowa, dyskursywna artykulacja.

Kategorią niekwestionowanie polityczną jest mowa, dzięki której jednostka staje się łącznikiem między porządkiem naturalnym a sferą publiczną. W języku przecinają się intymność, naturalność i polityka, pojmowana jako działanie istot mówiących. Dlatego to właśnie mowa i wykluczenie zwierząt ze wspólnoty istot mówiących są dla Joanny Bednarek zasadnicze, pozwalają bowiem zrozumieć trudności w nadaniu zwierzętom statusu podmiotów praw i polityki.

W kwestii stosunku do „zwierzęcia” - mówił Jacques Derrida - całą nowoczesność określa spuścizna kartezjańska ${ }^{6}$. „Teoria Kartezjusza zakłada, że język zwierząt jest systemem znaków bez odpowiedzi: reakcji tak, ale nie odpowiedzi. Immanuel Kant, Emmanuel Lévinas, Jacques Lacan, Martin Heidegger (a także kognitywiści) zajmują w tej kwestii stanowisko niemal

6 Przemoc wobec zwierząt. Jacques Derrida $w$ rozmowie z Élisabeth Roudinesco, „Znak” 2015, nr 5 (720), s. 36. 
identyczne z Kartezjuszem. Odróżniają reakcję od odpowiedzi"7. Połączenie języka z rozumnością zawdzięcza swój status właśnie Kartezjuszowi, porównującemu nieme zwierzęta do bezrozumnych, cielesnych maszyn. Nie są one „substancją myślącą”, a jedynie rozciągłą, więc zajmują miejsce w szeregu obok maszyn czy kamieni.

Joanna Bednarek traktuje Kartezjusza jako „czarny charakter dwudziestowiecznej filozofii” (s. 49), a jednocześnie stwierdza, iż najbardziej skandaliczne w stosunku ludzi do zwierząt jest ignorowanie, istniejących przecież, alternatywnych stanowisk: „mimo tego, że wielu nie wierzyło, iż zwierzęta są maszynami, powszechnie traktowano je tak, jak gdyby nimi były" (s. 57).

Wśród tych alternatywnych stanowisk można umieścić (jak robi to część posthumanistycznych badaczy i badaczek, szczególnie Rosi Braidotti) ontologię Barucha Spinozy, która umożliwia pomyślenie nowej teorii podmiotowości, uwolnionej od balastu zarówno klasycznego humanizmu, jak i antropocentrycznie zorientowanego antyhumanizmu. Zaktualizowany Spinozjański monizm pozwala przekroczyć myślenie w kategoriach wnętrza i zewnętrza, a zatem umożliwia usunięcie podziału na naturę i kulturę, który wydaje się bezsensowny w momencie, gdy „to, co jest ludzką istotą natury i naturalną istotą człowieka, staje się tożsame $\mathrm{w}$ naturze jako produkcji czy przemyśle, a zatem również w życiu gatunkowym człowieka"9. Odczytanie Spinozy przez Gilles'a Deleuze'a i Félixa Guattariego można traktować jako zwornik podmiotowości poddanej nieustannemu ruchowi, która nie zajmuje w świecie centralnej pozycji, ponieważ jest zdecentrowana, znajduje się nie $\mathrm{w}$ środku koła, lecz na jego brzegu. Taka podmiotowość łączy się ze światem, którego część stanowi; pozostaje zanurzona w spinozjańskiej, radykalnej immanencji. To ujęcie i odnowienie myśli Spinozy właściwe jest badaczom i badaczkom nowego materializmu, który zmierza m.in. do zerwania $\mathrm{z}$ językowym reprezentacjonizmem na rzecz performatywnej alternatywy - wysunięcia na plan pierwszy praktyk, czynów i działania. Jedna z badaczek, Karen Barad, przeciwstawiając się ,reprezentacjonistycznej fiksacji na słowach i rzeczach”, sięga do ontologii relacyjnej, która w konsekwencji pozwala rozpoznać doniosłość ,przyczynowej relacji między urządzeniami produkcji cielesnej i wytwarzanymi przez nie zjawiskami” i określić ją jako „sprawczą intra-akcję" ${ }^{10}$.

\section{Ibidem.}

8 Por. M. Markiewicz, Pomiędzy dziedzictwem Spinozy a wyzwaniami nowego materializmu. Tropy, „Praktyka Teoretyczna”, http://www.praktykateoretyczna.pl/milosz-markiewicz-pomiedzy-dziedzictwem-spinozy-a-wyzwaniami-nowego-materializmu-tropy/ [dostęp: 5.05.2018].

9 Ibidem.

10 K. Barad, Posthumanistyczna performatywność. Ku zrozumieniu jak materia zaczyna mieć znaczenie, przeł. J. Bednarek [w:] Teorie wywrotowe. Antologia przekładów, red. A. Gajewska, Poznań 2012, s. 339. 
Propozycja Barad, wywiedziona z interpretacji fizyki Bohra, zastępuje więc pojęcie ,interakcji” (zakładające uprzednie istnienie niezależnych bytów) relacją, którą cechuje wzajemna zależność, co w konsekwencji pozwala uznać, że ciała, nie tylko ludzkie, ,materializują się poprzez intra-aktywność świata jego performatywność" ${ }^{11}$. W konsekwencji nowy materializm, którego reprezentantką jest Barad, traktuje byty ludzkie jako „część świata w jego otwartym stawaniu się"12, a zatem odbiera człowiekowi uprzywilejowane, wyróżnione miejsce w świecie.

Nieco tylko inne spojrzenie na kwestię ,stawania się" proponuje Joanna Bednarek, dla której Spinozjański projekt intelektualny jest przede wszystkim związany z ujęciem natury jako ogarniającej rzeczywistość ludzką, a zatem „stan natury nie przestaje istnieć wraz z zawiązaniem się wspólnoty politycznej” (s. 59). Badaczka zwraca przy tym uwagę, że u Spinozy wykluczenie zwierząt nie jest, jak u Kartezjusza, przeźroczyste i niewidzialne, gdyż zatarte rozstrzygnięciami ontologicznymi i epistemologicznymi, lecz jest gestem, który należy nieustannie podtrzymywać, by zachować spójność ludzkiej wspólnoty.

Bednarek nie różni się także szczególnie od badaczy i badaczek nurtu nowego materializmu czy realizmu sprawczego, gdy sięga do Spinozy, by znaleźć w nim sojusznika dla przemyślenia kategorii życia, które dałoby się połączyć z mową, „bastionem polityczności”'13. Podążając za Deleuzjańską interpretacją Spinozy (tak istotną dla refleksji próbujących przekroczyć antropocentryzm), badaczka wydobywa jednocześnie obecne w tej interpretacji sprzeczności: „Nieatropocentryczna ontologia nie przeszkodziła Deleuze'owi w opisywaniu stawania-się-zwierzęciem jako procesu, którego najlepiej dokonuje sam człowiek, obywający się bez kontaktu z empirycznymi, molowymi zwierzętami" (s. 115).

Włączenie perspektywy polityczności i jej związku z życiem skłania Bednarek do krótkiego przyjrzenia się biopolityce w wydaniu Giorgia Agambena i Roberta Esposita. To nurt, który - jak pisze autorka - „charakteryzuje dość pesymistyczna wizja polityki" (s. 104), w ramach którego nie tylko kwestia empirycznych zwierząt pozostaje nieobecna, ale nieobecność ta prowadzi do utrzymania odczłowieczenia ludzi właśnie dlatego, że odmawia się praw

11 Ibidem, s. 351.

12 Ibidem, s. 348.

13 Z pewnym uproszczeniem można by powiedzieć, że najogólniejszym celem realizmu sprawczego jest, jak pisze Barad, przeformułowanie pojęć praktyk dyskursywnych i fenomenów materialnych oraz relacji między nimi. Joanna Bednarek czerpie wiele z rewizji ontologii dokonywanej w duchu realizmu sprawczego, jednak, jak sama wskazuje, ontologia w tej interpretacji nie prowadzi do żadnej określonej formy polityki, która byłaby przyjazna istotom innym niż ludzie. 
zwierzętom. W konsekwencji Bednarek wskazuje, że rozmontowanie maszyny antropocentrycznej jest niemożliwe bez podjęcia refleksji nad statusem samych zwierząt.

Wszystkie demaskacje niepełności nurtów, związanych przecież z krytyką antropocentrycznej logiki, znajdują zwieńczenie w ostatniej, tytułowej części eseju, stanowiącej jego najbardziej oryginalny fragment, uzasadniający także przekroczenie przez autorkę tak - wydawałoby się - poręcznych projektów, jakie oferuje realizm sprawczy i posthumanistyczna performatywność. Bednarek stara się zatem ominąć kontrowersje właściwe np. materialno-semiotycznej ontologii Donny Haraway, postulującej uznanie zwierząt laboratoryjnych za pracowników, co ostatecznie utrwala istniejące hierarchie i „usprawiedliwia zadawane zwierzętom cierpienia" (s. 115).

Poszukując rozwiązania pozwalającego uzupełnić spinozjańsko-deleuzjańską ontologię o emancypacyjny potencjał, a także przekroczyć ten nurt prozwierzęcych teorii, który czerpie z biopolityki negatywnej, Bednarek sięga do Jacques'a Rancière'a, którego koncepcja polityki pozwala uwidocznić równość istot mówiących. Badaczka korzysta z rozpoznania francuskiego filozofa, że polityka pozwala uczynić równość widoczną, a zatem „wydobywa na powierzchnię, czy też aktualizuje wirtualną równość, stanowiącą warunek możliwości relacji społecznej" (s. 117). I tutaj jednak, podobnie jak w wypadku omawianych wcześniej koncepcji Lévinasa, Esposita czy Agambena, Bednarek napotyka problem. Rancière uznaje bowiem, że „człowiek demokratyczny posiada umiejętność mówienia, a więc jest również bytem poetyckim, zdolnym do pojęcia dystansu pomiędzy słowem a rzeczą, który to dystans nie jest rozczarowaniem czy oszustwem, ale istotą człowieczeństwa, uwzględniającą nierealność przedstawienia" ${ }^{14}$. Francuski filozof konsekwentnie wskazuje na potrzebę udowodnienia przez podmioty polityki swojej rozumności i językowości, która jest czymś więcej aniżeli krzykiem, wyrażającym elementarne potrzeby życia. W tym miejscu Bednarek zachęca, by „nagiąć odrobinę” pojęcia Rancière'a, czyli przekroczyć logikę, w ramach której ,polityka zaczyna się dopiero wtedy, gdy życie ustępuje mowie” (s. 119-120). To „nagięcie” ma prowadzić do uwzględnienia biosemiotycznych diagnoz, uznających tożsamość życia i wytwarzania znaków. I choć jedynie człowiek posługuje się kodem symbolicznym, to przecież ,kod symboliczny jest tylko jednym z systemów znakowych" (s. 121). Co więcej, autorka Życia, które mówi... uznaje (za Gregorym Batesonem), że nawet w wypadku najprostszych organizmów widać aktywność semiotyczną, organizmy bowiem poznają otoczenie, ale również się do niego adaptują i w toku reprodukcji przekazują rezultaty zmian kolejnym pokoleniom, których budowa „ucieleśnia” efekty wpływu otoczenia. Przykład tak prostych organizmów jak pantofelek pozwala uznać, że

14 J. Rancière, Na brzegach politycznego, przeł. I. Bojadziijewa, J. Sowa, Kraków 2008, s. 93. 
odróżnianie funkcji ciała jako części rzeczywistości i umysłu, który odnosi się do niej, jest niemożliwe, bowiem umysł jawi się tu jako „system zawierający i mózg, i całe ciało, powiązane z otoczeniem" (s. 126).

Połączenie Rancière'owskiej polityczności z biosemiotycznymi zdobyczami w zakresie konceptualizowania mowy, przefiltrowane dodatkowo przez Deleuzjańskie rozumienie wolności (wolność to kwestia ekspresji istoty danego bytu), ma prowadzić do oparcia solidarności ze zwierzętami innymi niż ludzie nie na podobieństwie, lecz na powiązaniach, jako że „każdy organizm wytwarza i odczytuje znaki, ponieważ jest powiązany z innymi organizmami i nieożywionym otoczeniem" (s. 138). Polityka oparta na ontologii biosemiotycznej miałaby nie tyle konserwować te powiązania, ile postulować poszerzanie i tworzenie nowych sieci zależności, a zatem działać nie w horyzoncie faktyczności, lecz raczej inscenizować potencjalność - skuteczną broń przeciwko konserwującej i konserwatywnej hierarchii form życia.

Życie, które mówi... nie jest esejem, który proponuje praktyczne rozwiązania. Jak przyznaje na końcu książki autorka, ,,przełożenie tej poszerzonej empatii na język praw politycznych to jednak trudna sprawa" (s. 141) ${ }^{15}$. Trudna także dlatego, że Bednarek, kreśląc precyzyjny i przekonujący projekt wspólnoty opartej na przyległości i powiązaniach, za intuicyjne zrozumiałe uznaje samo pojęcie „Zwierzęcia” i jego definicję, często synonimicznie traktuje „Zwierzę” i to, co „nie-ludzkie”. Oczywiście perspektywa biosemiotyczna (w odróżnieniu od nowego materializmu) zakłada, że sprawczość i wytwarzanie znaków właściwe są bytom ożywionym, jednakże - jak przy innej okazji zauważał Arkadiusz Żychliński - ,sam termin »zwierzęta«, jako generalizująca liczba mnoga, sztucznie homogenizująca heterogeniczne byty staje się w tym momencie podejrzany" ${ }^{\prime 16}$. Równie problematyczna (gdyż w założeniu potraktowana jako oczywista) wydaje się kwestia konkretności praw, które miałyby przysługiwać zwierzętom jako niezauważonej przez nas części wspólnoty. Można założyć, że w grę wchodzą tu wszystkie prawa przypisane człowiekowi, ale pozostaje to niejasne w obliczu posługiwania się Rancière'owskim rozumieniem polityczności i demokracji. Wydaje się bowiem, że nie wystarczy tylko, jak postuluje autorka, „nagiąć odrobinę” jego pojęcie mowy i uwolnić je od tożsamości z używanym przez ludzi systemem znaków symbolicznych. Ten gest, rzecz jasna, skutecznie rozszerza kwestię przynależności do wspólnoty politycznej, nie interweniuje jednak w Rancière'owską strukturę społeczeństwa jako instytucji. „Jeśli równość - pisze autor Dzielenia postrzegalnego - stanowi prawo

$15 \mathrm{~W}$ rozmowie przeprowadzonej w związku z publikacją książki Bednarek wprost mówiła, że przede wszystkim rozwiązuje problem filozoficzny, akademicki, dotyczący definiowania życia przez nowoczesną metafizykę i politykę - ,Zwierzęta musiały być czujne”. Z Joanna Bednarek rozmawia Arkadiusz Gruszczyński, „Znak” 2018, nr 1 (752), s. 104.

${ }_{16}$ A. Żychliński, Zwierzę, którego nie ma. Experimentum de hominis natura, „Konteksty" 2009, nr 4, s. 52. 
wspólnoty, to społeczeństwo podlega nierówności. [...] Wspólnota równych nigdy nie ukryje wspólnoty nierównych, jednocześnie jednak nie mogą one istnieć bez siebie nawzajem" ${ }^{17}$. Wejście w (antropocentryczną) instytucję społeczeństwa, która ukrywa nierówność za „wyobrażeniową zasłoną Jedności”, wiązałoby się zapewne z przyjęciem przez Joannę Bednarek radykalnie odmiennej perspektywy, dlatego pozostaje ona na poziomie wspólnoty, a nie instytucji. Odnoszę jednak wrażenie, że „nagięcie” francuskiego filozofa i uczynienie $\mathrm{z}$ tego nagięcia fundamentu wspólnoty jest niewystarczające, choć to już zarzut z poziomu pewnej ,praktyczności”, której brak - w obliczu deklaracji autorki - nie powinien być tutaj podnoszony.

Życie, które mówi... jest esejem niezwykle ważnym nie tylko jako kolejny głos w ramach posthumanistycznych dyskusji, toczących się w gronie badaczy i badaczek już przekonanych o konieczności rewizji założycielskich aktów zachodniej metafizyki i polityki, ale przede wszystkim jako obiecująca potencjalność, której stawkę stanowi wspólnota, najpierw jako pewna idea, ale w konsekwencji być może również jako nasza wspólna praxis.

\section{Bibliografia}

Barad K., Posthumanistyczna performatywność. Ku zrozumieniu jak materia zaczyna mieć znaczenie, przeł. J. Bednarek [w:] Teorie wywrotowe. Antologia przekładów, red. A. Gajewska, Poznań 2012.

Bednarek J., Emancypacyjna obietnica posthumanizmu, „Praktyka Teoretyczna”, http://www.praktykateoretyczna.pl/joanna-bednarek-emancypacyjna-obietnicaposthumanizmu/\#_ftn6 [dostęp: 5.05.2018].

Bednarek J., Życie, które mówi. Nowoczesna wspólnota i zwierzęta, Warszawa 2017.

Elżanowski A., O podmiotach osobowych i nieosobowych, „Znak” 2015, nr 5 (720).

Gzyra D., Problem zwierząt. Jak postrzegamy i jak traktujemy zwierzęta?, „Jednak Książki. Gdańskie Czasopismo Humanistyczne” 2014, nr 2.

Janik M., Polityka nie-polityczności - nieme zwierzęta i posthumanizm, „Praktyka Teoretyczna" 2014, nr 4.

Markiewicz M., Pomiędzy dziedzictwem Spinozy a wyzwaniami nowego materializmu. Tropy, „Praktyka Teoretyczna”, http://www.praktykateoretyczna.pl/milosz-markiewicz-pomiedzy-dziedzictwem-spinozy-a-wyzwaniami-nowego-materializmutropy/ [dostęp: 5.05.2018].

Przemoc wobec zwierząt. Jacques Derrida $w$ rozmowie z Élisabeth Roudinesco, „Znak” 2015, nr 5 (720).

Rancière J., Na brzegach politycznego, przeł. I. Bojadżijewa, J. Sowa, Kraków 2008.

17 J. Rancière, op.cit., s. 141. 
„Zwierzęta musiały być czujne”. Z Joanna Bednarek rozmawia Arkadiusz Gruszczyński, „Znak” 2018, nr 1 (752).

Żychliński A., Zwierzę, którego nie ma. Experimentum de hominis natura, „Konteksty" 2009, $\mathrm{nr} 4$. 